\title{
Effects of redox processes on soil acidity
}

\author{
N. van Breemen
}

Department of Soil Science and Geology, Wageningen Agricultural University, P.O. Box 37. NL 6700 AA Wageningen, Netherlands

Received 24 April 1987; accepted 15 June 1987

Key words: chemical reduction, $\mathrm{pH}$ change, ferrolysis, soil acidification, soil alkalinization, acid sulfate soils, sulfate reduction, denitrification

\section{Summary}

Redox processes due to alternating aerobic and anaerobic conditions may give rise to strongly acidic or alkaline soils and waters. First, oxidized chemical components tend to be more acidic or less alkaline than their reduced counterparts. Second, and more important, redox processes often lead to the simultaneous formation of acidic (or potentially acidic) and alkaline substances with different mobility (dissolved or gaseous versus adsorbed or solid), so that one of the two substances can be exported, leaving a more acidic or more alkaline residue. Examples of acidification or alkalinization processes in wetlands based on these principles are: (1) formation of acid sulfate soils (transformation of seawater sulfate and sedimentary iron to immobile potential acidity $\left(\mathrm{FeS}_{2}\right)$ and mobile alkalinity $\left(\mathrm{HCO}_{3}^{-}\right)$, followed by oxidation of $\mathrm{FeS}_{2}$ after the alkalinity has disappeared), (2) alkalinization of periodically flooded acid sulfate soils (formation of dissolved ferrous sulfate during reduction, and oxidation of the ferrous sulfate to ferric oxide and sulfuric acid at the soil surface, followed by drainage of the acid floodwater), (3) ferrolysis (immobilization of seasonally reduced ferric iron as exchangeable $\mathrm{Fe}^{2+}$, and removal of replaced bases by drainage, followed by oxidation of $\mathrm{Fe}^{2+}$-clay to $\mathrm{H}^{+}$-clay), and (4) soil alkalinization in closed depressions (reduction of sodium sulfate to sodium (hydrogen) carbonate and volatile $\mathrm{H}_{2} \mathrm{~S}$ ).

\section{Introduction}

Oxidation and reduction processes in periodically drained wetlands and at boundaries of oxidized and reduced zones in sediments and waters may have important effects on $\mathrm{pH}$, alkalinity and acidity (Ponnamperuma, 1972). Dramatic cases of soil acidification or alkalinization due to redox processes in wetlands include acid sulfate soils (van Breemen, 1976), formation of sodium carbonate in submerged saline soils (Janitsky \& Whittig, 1964), and the process of ferrolysis (Brinkman, 1979). The aim of this paper is to outline the principles involved in soil acidification or al- 
kalinization under the influence of redox processes, applying a recently developed general approach to describe soil acidification/alkalinization (van Breemen et al., 1983; van Breemen, 1987b).

Acidification and alkalinization of soils can be characterized by capacity and intensity factors. A titration curve combines these two factors: the horizontal axis usually refers to the capacity factor and may show the amount of strong acid added, while the vertical axis shows the intensity factor, e.g. the $\mathrm{pH}$ or the degree of base saturation of the exchange complex. Hypothetical titration curves of a calcareous clay soil to which strong acid is added slowly or quickly are shown in Fig. 1. The curves illustrate that the value of the intensity factor does not change in a simple manner with the amount of $\mathrm{H}^{+}$added, due to stronger buffering in certain $\mathrm{pH}$ ranges: buffering by $\mathrm{CaCO}_{3}$ around $\mathrm{pH} 7$, and by exchangeable bases between $\mathrm{pH} 5$ and 4. Furthermore, Fig. 1 shows that quick addition of strong acid depresses the $\mathrm{pH}$ more strongly than slow addition. This kinetic effect is due to the fact that relatively slow buffer reactions, e.g. the dissolution (weathering) of silicate minerals, can consume more $\mathrm{H}^{+}$upon slow than upon quick addition of strong acid. Because $\mathrm{pH}$ cannot be predicted in a simple manner from the amount of acid (or base) added, it is not a convenient parameter for defining soil acidification. Here we will express soil acidification or alkalinization in terms of capacity factors: the amounts of strong acid or strong base added, or the changes in the acid- or base-neutralizing capacity (ANC or BNC) of a soil system. This choice is not only a matter of convenience: changes in the components making up the ANC of the soil often directly reflect the processes responsible for changing ANC. To translate $\triangle \mathrm{ANC}$ into changes in the ecologically more relevant intensive parameters such as soil $\mathrm{pH}$ and base saturation, one needs realistic, kinetically relevant titration curves.

The ANC of mineral soil material, $\mathrm{ANC}_{(\mathrm{S})}$, is made up of contributions by the solid phase, $\mathrm{ANC}_{(\mathrm{s})}$, and the aqueous phase, $\mathrm{ANC}_{(\mathrm{aq})}$ :

$$
\mathrm{ANC}_{(\mathrm{S})}=\mathrm{ANC}_{(\mathrm{s})}+\mathrm{ANC}_{(\mathrm{aq})}
$$

Although, due to the very wide mass ratio of solid to dissolved components in soils, $\mathrm{ANC}_{(\mathrm{aq})}$ is quantitatively negligible compared to $\mathrm{ANC}_{(\mathrm{s})}$, the distinction between the two is useful when describing soil acidification or alkalinization. $\mathrm{ANC}_{(\mathrm{s})}$ is equal

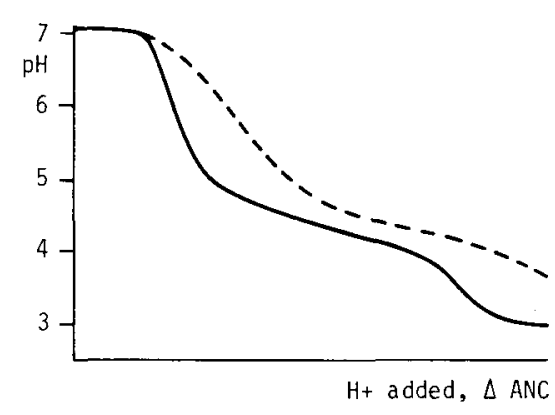

272
Fig. 1. Hypothetical titration curve of a calcareous clay soil upon slow (broken line) or quick (solid line) acidification. 
to the quantities of basic solid components minus those of acidic components. What is 'acidic' or 'basic' depends on the reference $\mathrm{pH}$ chosen. When titrating a soil down to $\mathrm{pH} 5, \mathrm{CaO}, \mathrm{MgO}, \mathrm{K}_{2} \mathrm{O}, \mathrm{Na}_{2} \mathrm{O}, \mathrm{FeO}$ and $\mathrm{NH}_{3}$ are basic components: they may accept protons, for example, according to the reaction:

$$
\mathrm{CaO}+2 \mathrm{H}^{+} \rightarrow \mathrm{Ca}^{2+}+\mathrm{H}_{2} \mathrm{O}
$$

$\mathrm{SO}_{3}, \mathrm{P}_{2} \mathrm{O}_{5}$ and $\mathrm{HCl}$, on the other hand, are acidic:

$$
\mathrm{SO}_{3}+\mathrm{H}_{2} \mathrm{O} \rightarrow 2 \mathrm{H}^{+}+\mathrm{SO}_{4}^{2-}
$$

At a reference $\mathrm{pH}$ of $3, \mathrm{Al}_{2} \mathrm{O}_{3}$ must be included as a basic component, because of the appreciable solubility of aluminium at low $\mathrm{pH}$ :

$$
\mathrm{Al}_{2} \mathrm{O}_{3}+3 \mathrm{H}^{+} \rightarrow \mathrm{Al}^{3+}+3 \mathrm{H}_{2} \mathrm{O}
$$

Most other components in soils are either too weakly acidic $\left(\mathrm{SiO}_{2}, \mathrm{CO}_{2}, \mathrm{H}_{2} \mathrm{O}, \mathrm{H}_{2} \mathrm{~S}\right)$ or too weakly alkaline $\left(\mathrm{Fe}_{2} \mathrm{O}_{3}\right)$ to release or accept protons at the reference $\mathrm{pH}$ values of 3 or 5 . So,

$$
\begin{aligned}
\mathrm{ANC}_{(\mathrm{s}, \mathrm{pH} 5)}= & 2[\mathrm{CaO}]+2[\mathrm{MgO}]+2\left[\mathrm{~K}_{2} \mathrm{O}\right]+2\left[\mathrm{Na}_{2} \mathrm{O}\right]+2[\mathrm{FeO}]+\left[\mathrm{NH}_{3}\right]- \\
& 2\left[\mathrm{SO}_{3}\right]-2\left[\mathrm{P}_{2} \mathrm{O}_{5}\right]-[\mathrm{HCl}]-2\left[\mathrm{~N}_{2} \mathrm{O}_{5}\right]
\end{aligned}
$$

with brackets denoting molar quantities. The components in Eq. 5 may be present in crystalline, amorphous or sorbed form. Disregarding trace elements, all quantitatively important mineral substances in soils can be considered to consist of the components listed so far, added in various molar proportions. Nitrate- $\mathrm{N}\left(\mathrm{N}_{2} \mathrm{O}_{5}\right)$ is highly soluble and can be neglected as a solid component in all but the most arid soils.

Aqueous acid neutralizing capacity, $\mathrm{ANC}_{(\mathrm{aq}, \mathrm{pH} 5)}$ could be written in terms of the components of Eq. 5 but is usually ascribed to alkalinity due to carbonate plus organic $\left(\mathrm{A}^{-}\right)$anions, minus free mineral acidity:

$$
\mathrm{ANC}_{(\mathrm{aq}, \mathrm{pH} 5)}=\left[\mathrm{HCO}_{3}^{-}\right]+2\left[\mathrm{CO}_{3}^{2-}\right]+\left[\mathrm{OH}^{-}\right]+\left[\mathrm{A}^{-}\right]-\left[\mathrm{H}^{+}\right]
$$

In summary, soil acidification and soil alkalinization can be defined in terms of addition or removal of the components of Eq. 5, as follows:

$$
\text { soil acidification }=-(\text { soil alkalinization })=-\Delta \mathrm{ANC}_{(\mathrm{S}, \mathrm{pH} 5)}
$$

Changes in $\mathrm{ANC}_{(\mathrm{S})}$ resulting from transfer of solid matter, for instance by erosion and sedimentation, will not be considered here, and I will deal only with changes in $\mathrm{ANC}_{(\mathrm{S})}$ resulting from processes (including addition or removal of dissolved substances) in a given bulk of solids and solutes that makes up a soil. Practically all such acidification and alkalinization processes can be seen as consequences of (1) addi- 
tion of dissolved strong acids and bases, (2) soil internal production of various acids, (3) the effects of assimilation by biota, and (4) reduction-oxidation processes. Here, attention will be paid only to the effect of redox processes. Examples of the effects of other processes on $\mathrm{ANC}_{(\mathrm{S})}$ have been described elsewhere (van Breemen et al., 1983; van Breemen, 1987b).

\section{Effect of redox on $\mathrm{ANC}_{(\mathrm{S})}$ and $\mathrm{pH}$ in soil systems closed for exchange of solutes and gases}

A well-known effect of waterlogging of soils is that the $\mathrm{pH}$ of acidic soils increases, and that the $\mathrm{pH}$ of alkaline soils decreases, while the $\mathrm{pH}$ generally stabilizes at values between approximately 6 and 7 after several weeks or months of flooding (Ponnamperuma, 1972). The increase in $\mathrm{pH}$ of initially acidic soils is a consequence of chemical reduction of acidic $\left(\mathrm{N}_{2} \mathrm{O}_{5}, \mathrm{SO}_{3}\right)$ or 'inert' $\left(\mathrm{Fe}_{2} \mathrm{O}_{3}\right)$ components to their reduced basic $\left(\mathrm{NH}_{3}, \mathrm{FeO}\right)$ or weakly acidic $\left(\mathrm{H}_{2} \mathrm{~S}\right)$ counterparts under the influence of organic matter. Inspection of $\mathrm{Eq} .5$ shows that chemical reduction of each of the three oxidized components causes $\mathrm{ANC}_{(\mathrm{s})}$ to increase.

In most reduced soils the transformation of iron is quantitatively most important, and this process will be described in some detail. If an aerobic soil containing metabolizable organic matter is submerged, the rate of oxygen consumption by microorganisms normally exceeds the rate of supply of $\mathrm{O}_{2}$ from the atmosphere. Generally, $\mathrm{O}_{2}$ concentrations drop to very low levels within a few days, and ferric oxide (e.g. goethite $(\alpha \mathrm{FeOOH})$ or ferrihydrite $\left.\left(\mathrm{Fe}_{2} \mathrm{O}_{3} \cdot \mathrm{H}_{2} \mathrm{O}\right)\right)$ takes over the role of $\mathrm{O}_{2}$ as electron acceptor in the oxidation of organic matter $\left(\mathrm{CH}_{2} \mathrm{O}\right)$ :

$$
\mathrm{Fe}_{2} \mathrm{O}_{3(\mathrm{~s})}+1 / 2 \mathrm{CH}_{2} \mathrm{O} \rightarrow 2 \mathrm{FeO}_{(\mathrm{s})}+1 / 2 \mathrm{CO}_{2(\mathrm{~g})}+1 / 2 \mathrm{H}_{2} \mathrm{O}
$$

The bulk of the reduced iron is solid or adsorbed, but up to a few percent of it appears in solution as $\mathrm{Fe}^{2+}$, normally accompanied by hydrogen carbonate or organic anions. Formation of ionic $\mathrm{Fe}^{2+}$ involves consumption of $\mathrm{H}^{+}$:

$$
\mathrm{Fe}_{2} \mathrm{O}_{3}+1 / 2 \mathrm{CH}_{2} \mathrm{O}+4 \mathrm{H}^{+} \rightarrow 2 \mathrm{Fe}^{2+}+1 / 2 \mathrm{CO}_{2}+3 / 2 \mathrm{H}_{2} \mathrm{O}
$$

which directly explains the increase in $\mathrm{pH}$. Proton donors may be adsorbed aluminium (causing a forced exchange of $\mathrm{Fe}^{2+}$ for $\mathrm{Al}^{3+}$, which is precipitated as aluminium hydroxyde; cf. Cate \& Sukhai, 1964) or $\mathrm{CO}_{2}$ or organic acids (causing the appearance of hydrogen carbonate and organic anions along with $\mathrm{Fe}^{2+}$; cf. van Breemen, 1987a). The $\mathrm{pH}$ normally stabilizes at between 6 and 7 , at a value which can be explained by equilibria involving ferrous hydroxide (or ferrous carbonate), ferric oxide, dissolved ferrous iron and $\mathrm{CO}_{2}$. If the initial (aerobic) soil $\mathrm{pH}$ exceeds 7 , the solubility of $\mathrm{FeO}$-containing phases is too low to produce appreciable ionic $\mathrm{Fe}^{2+}$, and the $\mathrm{pH}$-depressing effect of $\mathrm{CO}_{2}$ produced generally exceeds the $\mathrm{pH}$-increasing effect of the reduction of iron. The result is a decrease in $\mathrm{pH}$ (in spite of an increase in $\mathrm{ANC}_{(\mathrm{S})}$ !).

When a waterlogged soil dries out so that air can penetrate, $\mathrm{FeO}$ is oxidized 


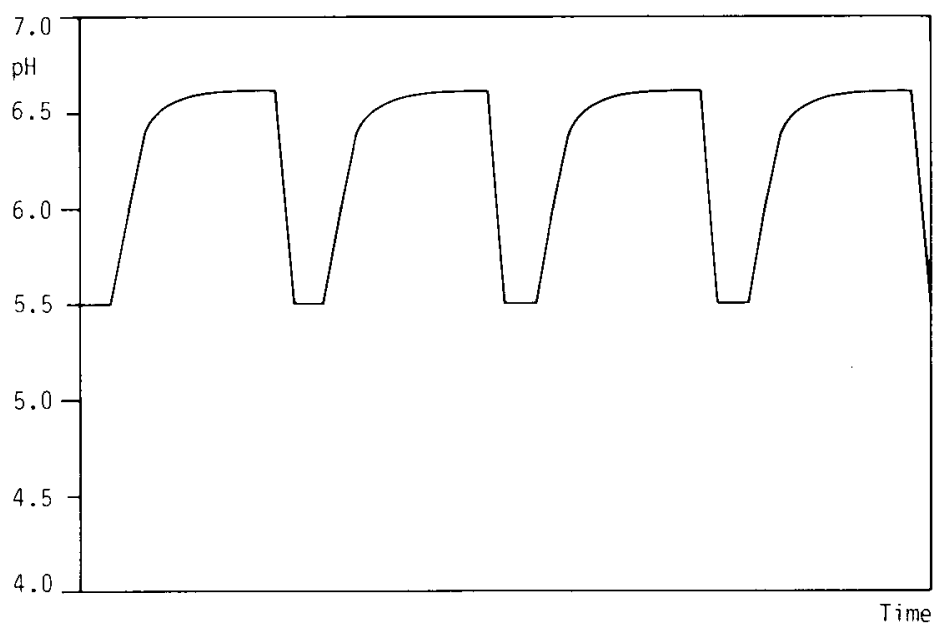

Fig. 2. Temporal variation in $\mathrm{pH}$ in seasonally flooded soils; each cycle refers to one year (hypotheti(al).

quickly to $\mathrm{Fe}_{2} \mathrm{O}_{3}$, causing the $\mathrm{pH}$ to revert to the previous (aerobic) value. Seasonal cycling of oxidized and reduced conditions thus causes a fluctuation of $\mathrm{ANC}_{(\mathrm{S})}$ and $\mathrm{pH}$ as shown in Fig. 2. So $\mathrm{ANC}_{(\mathrm{S})}$ and $\mathrm{pH}$ switch back and forth seasonally, with the oxidation of organic matter as the only net change taking place. Clearly, to keep the cycle going, fresh organic matter must be supplied regularly.

\section{Effect of redox on $\mathrm{ANC}_{(\mathrm{S})}$ and $\mathrm{pH}$ in soil systems open for exchange of solutes and gases}

As will be shown below, redox processes often lead to the formation of pairs of acidic (or potentially acid) and basic components of widely different mobility. If the soil system is open for removal of the most mobile components by leaching or volatilization, at least part of the change in $\mathrm{ANC}_{(S)}$ due to the redox reaction will be permanent. Examples of such permanent changes in ANC are (1) the formation of acid sulfate soils, (2) alkalinization of periodically flooded surface horizons of acid sulfate soils, (3) the process of ferrolysis, and (4) alkalinization by volatilization of $\mathrm{H}_{2} \mathrm{~S}$ or gaseous $\mathrm{N}$ from reduced soils. Each of these will be described in some detail below.

\section{Acid sulfate soils}

Formation of acid sulfate soils (Kittrick et al., 1982) is preceded by a reduced stage (generally in tidal marshes). In this stage ferrous sulfide (or pyrite) is formed by reduction of sulfate from seawater and sedimentary iron, while dissolved hydrogen carbonate (plus the cation that was associated with the sulfate, $M$ in Fig. 3) are removed by diffusion or by convection due to tidal action. $\mathrm{ANC}_{(\mathrm{S})}$ increases due to the $\mathrm{Fe}_{2} \mathrm{O}_{3} \rightarrow \mathrm{FeO}$ transformations, as was described previously. More important, 


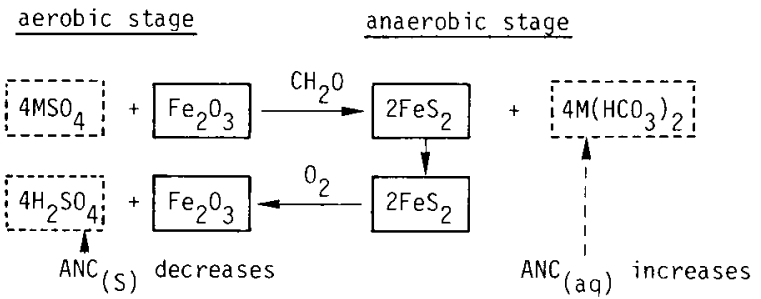

Formation of acid sulfate

soils and formation of

acid surface horizons in

non-acid marine soils

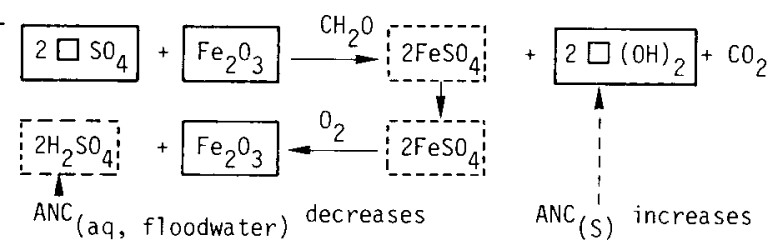

Alkalinization of periodic-

ally flooded surface

horizons of acid

sulfate soils

Ferrolysis
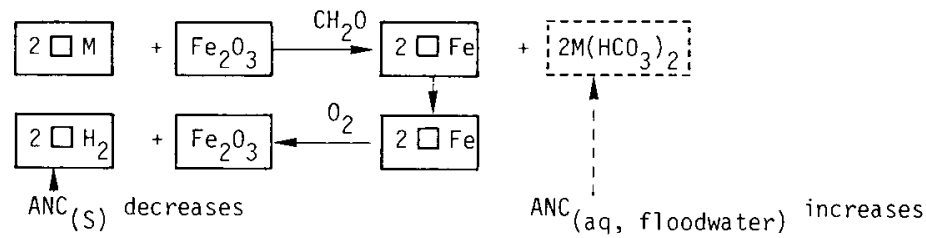

Alkalinization of soils and waters by sulfate reduction and $\mathrm{H}_{2} \mathrm{~S}$

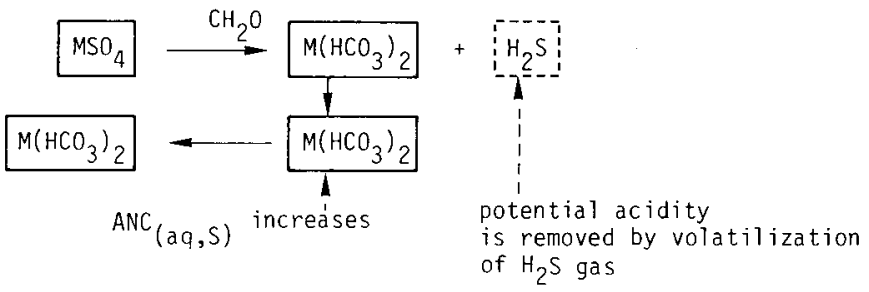

Fig. 3. Diagram illustrating the chemical changes in alternating aerobic (left) and anaerobic (right) soils. Components in solid rectangles are immobile, components in broken-line rectangles are mobile. Small squares denote exchange sites. $\mathrm{M}$ stands for a divalent cation $\left(\mathrm{Ca}^{2+}\right.$ or $\left.\mathrm{Mg}^{2+}\right)$, and $\mathrm{CH}_{2} \mathrm{O}$ refers to oxidizable organic matter.

however, is that sulfate $\left(\mathrm{MSO}_{4}\right)$ from seawater is 'split' into mobile alkalinity $\left(\mathrm{M}\left(\mathrm{HCO}_{3}\right)_{2}\right)$ and immobile potential acidity $\left(\mathrm{FeS}_{2}\right)$ that stays behind in the sediment. Over several years to decades, appreciable amounts of sulfide can be accumulated in tidal sediments.

Upon drainage of such marshes, oxidation of iron sulfide leads to strong acidification by formation of $\mathrm{H}_{2} \mathrm{SO}_{4}$. As a result, $\mathrm{ANC}_{(\mathrm{S})}$ decreases by a combination of base cation leaching by sulfuric acid, and by an increase in the $\mathrm{SO}_{3}$ content of the soil. If, during the reduced stage, $\mathrm{M}\left(\mathrm{HCO}_{3}\right)_{2}$ were retained in the system, e.g. as precip- 
itated carbonate, the acidity formed in sulfide oxidation would have been neutralized exactly by the carbonate formed, without permanent change in ANC.

A similar process involving formation of $\mathrm{FeS}$, not $\mathrm{FeS}_{2}$, in young non-acid marine clay soils (which still contain appreciable dissolved sulfate of seawater origin) may lead to a rapid acidification of seasonally flooded surface soils (van Breemen, 1975).

Alkalinization of periodically flooded surface horizons of acid sulfate soils

When acid sulfate soils are flooded and undergo reduction, ferrous sulfate, not ferrous hydrogen carbonate, appears in the soil solution (Fig. 3). This is because sulfate adsorbed on positive colloids or basic iron sulfates or aluminum sulfates (e.g. jarosite and jurbanite) serve as proton donors in the reduction of ferric iron (cf. Eq. 8). Part of the ferrous sulfate is oxidized at the interface between the soil and the surface water, producing a ferric oxide coating on the soils surface and releasing sulfuric acid in the floodwater. The ferrous sulfate concentration gradient caused by these processes promotes further transport of ferrous sulfate to the soil surface. Lateral drainage of the acid floodwater will lead to a permanent increase in $\mathrm{ANC}_{(S)}$ by removal of $\mathrm{SO}_{3}$. This process (van Breemen, 1975) can be of practical importance, both in the amelioration of acid sulfate soils, and in (unwanted) surface water acidification (e.g. in fishponds in acid sulfate soil areas).

\section{Ferrolysis}

The soil acidification taking place in the process of ferrolysis (Brinkman, 1979) resembles that involved in the formation of acid sulfate soils. In ferrolysis, however, exchangeable ferrous iron takes the place of ferrous sulfide as the immobile, poten-

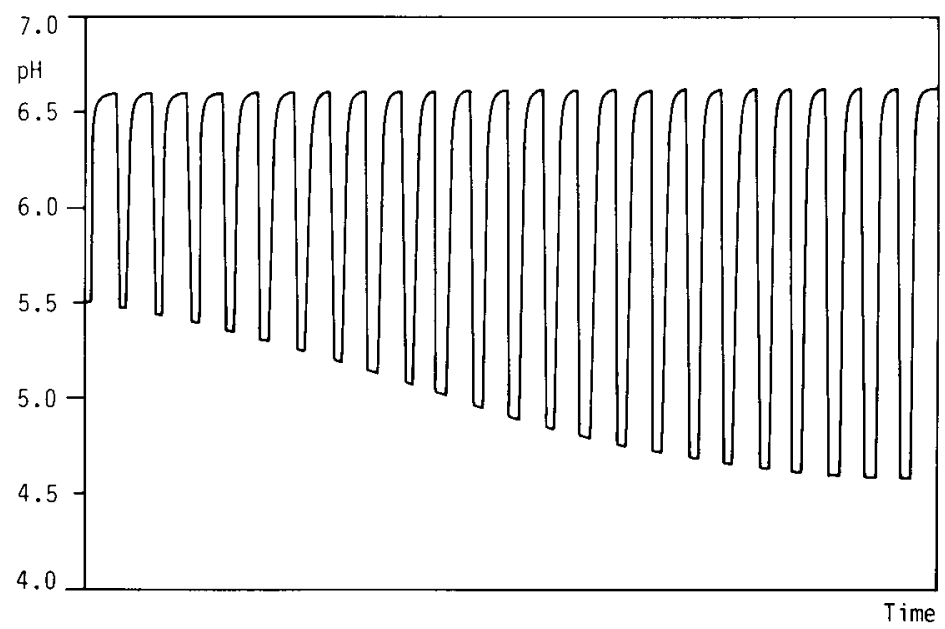

Fig. 4. Temporal variation in $\mathrm{pH}$ in a seasonally flooded soil undergoing ferrolysis; each cycle refers to one year (hypothetical). 
tially acid substance formed during reduction, while exchangeable $\mathrm{H}^{+}$is the acidic product formed after oxidation of exchangeable ferrous iron (Fig. 3). Ferrolysis is typical for soils of older river- or marine terraces in monsoon climates which have a seasonal perched water-table, caused by submergence with rain water. In those conditions, hydrology favours either lateral or vertical drainage, and, hence, removal of bases liberated from the exchange complex by ferrous iron. Over a number of years, the permanent decrease in $\mathrm{ANC}_{(\mathrm{S})}$ is reflected by a decrease in the $\mathrm{pH}$ of the aerobic, non-flooded soil (Fig. 4). Every year, however, upon flooding the $\mathrm{pH}$ will return to a value between 6 and 7 , the equilibrium $\mathrm{pH}$ of the ferrous hydroxide (or ferrous carbonate)-ferric oxide- $\mathrm{CO}_{2}$ system.

\section{Alkalinization by volatilization of $\mathrm{H}_{2}$ S or gaseous $\mathrm{N}$-species from reduced soils}

Closed depressions which accumulate sulfate-containing runoff in arid to semi-arid areas may become highly alkaline after volatilization of $\mathrm{H}_{2} \mathrm{~S}$ from sulfate reduction, and retention of $\mathrm{M}\left(\mathrm{HCO}_{3}\right)_{2}$ in a saline-alkaline lake or marsh (Fig. 3). The difference with acid sulfate soil formation is that here the system is losing more $\mathrm{H}_{2} \mathrm{~S}$ (potential acidity) to the atmosphere, than $\mathrm{M}\left(\mathrm{HCO}_{3}\right)_{2}$ (actual alkalinity) by drainage. So, the effect is the reverse of that in acid sulfate soil formation, and the system undergoes a permanent alkalinization. If the system would reoxidize, it would only reacidify partly, viz to the extent that reduced sulfur has been retained in the system (e.g. as FeS) and is available for the formation of sulfuric acid. As described by Janitzky \& Whittig (1964), sodium rather than a divalent cation is usually involved in this process. Eventually $\mathrm{Na}_{2} \mathrm{CO}_{3}$ may accumulate, leading to $\mathrm{pH}$ values well above 9.

A similar process has been described recently by Kelly et al. (1982) and Kilham (1982) in lakes receiving runoff from areas affected by acid atmospheric deposition. By sulfate reduction, denitrification and assimilation of nitrate by aquatic plants, such lakes could become more alkaline. Seen in a broader perspective, soils in the watersheds acidify by neutralizing acidic deposition (sulfuric and nitric acid), resulting in export of base cations as sulfates and nitrates into streams and lakes. After reduction of the strongly acid components sulfate and nitrate to weakly acidic $\left(\mathrm{H}_{2} \mathrm{~S}\right)$ and inert $\left(\mathrm{N}_{2}\right)$ components in the stream or lake bottom, the cations betray their basic origin by balancing the hydrogen carbonate formed during sulfate reduction and denitrification, e.g.:

$$
\mathrm{SO}_{4}^{2-}+2 \mathrm{CH}_{2} \mathrm{O} \rightarrow \mathrm{H}_{2} \mathrm{~S}+2 \mathrm{HCO}_{3}^{-}
$$

The alkalinization due to denitrification is permanent, but alkalinization due to sulfate reduction would be temporary if $\mathrm{H}_{2} \mathrm{~S}$ were fixed as iron sulfide and became oxidized later.

\section{Conclusions}

Redox processes can cause strong acidification or alkalinization in soils and aquatic environments for two main reasons. Oxidized components happen to be more acid- 
ic $\left(\mathrm{SO}_{3}, \mathrm{~N}_{2} \mathrm{O}_{5}\right)$ or less basic $\left(\mathrm{Fe}_{2} \mathrm{O}_{3}\right)$ than their reduced counterparts $\left(\mathrm{H}_{2} \mathrm{~S}, \mathrm{~N}_{2}, \mathrm{NH}_{3}\right.$, $\mathrm{FeO}$ ). As a result, alkalinity and $\mathrm{pH}$ of soil and water tend to increase upon chemical reduction, and to decrease upon oxidation. With the exception of denitrification to $\mathrm{N}_{2}$, these processes are fully reversible on a seasonal timescale.

On the other hand, however, changes in ANC may become permanent, because redox reactions often cause the formation of pairs of components that differ both in acid-base strength, and in mobility. Depending on whether the acidic or the basic component is the more mobile one, removal of one of the pair of components leads to a 'residue' system that has become permanently acidified or alkalinized. A number of examples, all variations on the same theme, have been illustrated in this paper.

\section{References}

Breemen, N. van, 1975. Acidification and deacidification of coastal plain soils as a result of periodic flooding. Soil Science Society of America Proceedings 39: 1153-1157.

Breemen, N. van, 1976. Genesis and soil solution chemistry of acid sulfate soils in Thailand. Agricultural Research Reports 848, Pudoc, Wageningen, 263 pp.

Breemen, N. van, J. Mulder \& C. T. Driscoll, 1983. Acidification and alkalinization of soils. Plant and Soil 75: 283-308.

Breemen. $N$. van. 1987a. Effects of seasonal redox processes involving Fe on the chemistry of periodically flooded soils. In: J. W. Stucki et al. (Eds.), Iron in soils and clay minerals. 797-812. Nato Asi Series. Reidal. Dordrecht. Netherlands.

Brecmen, N. van, 1987b. Soil acidification and alkalinization. Transactions 13 th Congress of the International Society of Soil Science (Hamburg. 1986), Vol. V, p. 85-90.

Brinkman. R.. 1979. Ferrolysis, a soil-forming process in hydromorphic conditions. Agricultural Research Reports 887, Pudoc, Wageningen, $106 \mathrm{pp}$.

Cate, R. B. \& A. P. Sukhai, 1964. A study of aluminium in rice soils. Soil Science 98: 85-93.

Janitzky, P. \& L. D. Whittig, 1964. Mechanism of formation of $\mathrm{Na}_{2} \mathrm{CO}_{3}$ in soils. II. Laboratory study of biogenesis. Journal of Soil Science 15: 145-147.

Kelly, C. A., J. W. M. Rudd, R. B. Cook \& D. W. Schindler, 1982. The potential importance of bacterial processes in regulating lake water acidification. Limnology and Oceanography 27: 868-882.

Kittrick, J. A., D. S. Fanning \& L. R. Hossner (Eds.), 1982. Acid sulfate weathering. SSSA Special Publication 10, Soil Science Society of America, Madison, WI, U.S.A., 234 pp.

Kilham, P., 1982. Acid precipitation: its role in the alkalinization of a lake in Michigan. Limnology and Oceanography 27: 857-867.

Ponnamperuma, F. N., 1972. The chemistry of submerged soils. Advances in Agronomy 24: 29-96. 